\title{
Editorial
}

$\mathrm{L}$ anguage and its development is a topic of perennial interest, and particularly so in relation to schooling. After all, it is supposed to be what distinguishes us from animals. Universal and compulsory education systems were established towards the end of the 19th century. At that time psychologists were in the process of establishing themselves as scientists, and psychology became the area of academic study which was called on to explain the processes of education. Psychologists offered advice, based on their own theories, on aspects of the testing, training and development of language. However, language and its structure, meaning, use, its settings and expression in both oral and visual forms have been studied more intensively by linguists of different kinds, and it is good to see reported in this issue investigations which draw on linguistic understanding.

This issue of set includes three contributions specifically on the topic of language. One tells of an exploration into the learning of spelling. The second is about teachers who were taught ways to manage the classroom discourse of young school children. The third tells of secondary school teachers who concentrated on making the specialised vocabulary of their subject clear to students. These last two studies share a particular concern for the English language competence of Pasifika students. I also see a link with language in two of the other articles. One is on the interpretation of graphs as texts and the other is on Pasifika students reporting on their secondary schooling and the way many of their teachers spoke to them.

The English system of spelling has been evolving since about the 7th century, and the symbols making up the words do not always match sounds in a regular manner. There have been efforts to reform English spelling, but would we really want to abandon spelling bees? In the meantime, we are stuck with a confusing set of symbols and sounds. Most 4-yearolds know what writing is and can tell you whether or not they can write. If they reproduce a letter of the alphabet it is usually the first letter of their own name. The beginning of spelling! Helen Pentecost and John Dickie take things much further than that with a study of Year 4 boys and girls, some of whom were making average progress in spelling, and some of whom were not. The children in the study were first asked to write their own stories and were then interviewed to describe how they worked out how to spell the words they needed. The authors argue that learning lists of spelling words is not a very productive method, especially for the less able. They recommend knowledge of the meaning structure of words, as well as the sounds of symbols. The study demonstrates that one can get great data with quite a small sample if children are given ample time to explain their thinking.

Susan Gray makes the point that learning the language of an academic subject is like learning a second language. In her article she writes about a small group of secondary teachers who had taken a course in Teaching English to Speakers of Other Languages (TESOL). From this vantage point, pairs of secondary mathematics, social studies and science teachers delivered lessons based on second-language-learning principles. The outcomes were very encouraging, demonstrating, as with the spelling study, that a small 
sample is not necessarily a barrier to convincing results.

The study of 5- and 6-year-olds in low socioeconomic schools by Jannie van Hees takes us into Year 1 and Year 2 classrooms to meet a small group of children, most of whom, although born in New Zealand, came from homes where a Pacific language was spoken. The children were first tested for their ability to express themselves. Their teachers were then trained to change their own speech from the familiar "question and expect a brief answer" format to give children more opportunity to join in with collaborative discussion. In this article, the evidence of classroom discourse has come from whole-class groups interacting with an adult. Some readers might be interested in the style of speech when the setting changes to children in pairs engaged in a teaching task without teacher intervention. An earlier set article (McDonald \& Kidman, 1991) sheds some light on this.

Like the children who explained their spelling strategies, Annie Siope offers a view of schooling in New Zealand through self-report, at first through her own eyes and then through the eyes of Pasifika students who were at secondary school a generation later. I wondered whether the students' accounts would refer in any way to language issues, since the topic is so important to teachers. They do, but the problem was not meaning. The students were troubled by the way in which teachers spoke to them and the emotional tone of the utterances. They appeared to want expressions that were warm and encouraging.

Texts are often thought of in terms of written language. Rosemary Hipkins points out that graphs are texts and a form of visual communication. Her article supplies some graphs and discusses them as tasks for interpretation. I attempted the early examples with, I am pleased to report, reasonable success, but the last graph was harder to fathom. All became clear when the author provided some extra information in written form that could not be deduced from the graphs themselves; providing an example of the value of more than one means of delivery. And so I came to know the enemies of the takahè.
Not all the articles relate to the development of language. As a whole, however, they indicate trends in our educational research. The previously mentioned articles relating to Pasifika students clearly shape one theme. Of the other articles, Penni Cushman and Tracy Clelland write about bullying - a current concern - and argue the value of a health promoting schools approach to its prevention. Kathrin Otrel-Cass, Bronwen Cowie and Elaine Khoo demonstrate how primary school science can be enhanced by using established and new information and communication technologies. Their account includes a photograph of two boys using an interactive whiteboard together with Google Earth to work out how rivers shape the landscape. There is a helpful guide to understanding errors in assessments. Finally, Dawn Lawrence reflects on her introduction to the "culturally responsive pedagogy of relations" in Te Kotahitanga. Her article suggests that the usual focus of research on language - that is, what the children say-will increasingly be expanded to include what the teachers say and whether this contributes to the wellbeing of their Māori students.

This issue of set is an interesting account of research, often carried out in collaboration with classroom teachers, on contemporary issues.

\section{Geraldine McDonald}

\section{Reference}

McDonald, G., \& Kidman, J. (1991). Ten days in new entrant classrooms. set: Research Information for Teachers, 2, item 14.

DR GERALDINE MCDONALD joined NZCER in 1974 to establish the Early Childhood Unit. She was Assistant Director from 1977 to 1992 and later taught at Wellington College of Education and Victoria University of Wellington. Her research interests include literacy and the demographic structure of education systems. 